\title{
Resistance to tumour challenge after tumour laser thermotherapy is associated with a cellular immune response
}

\author{
K Ivarsson', L Myllymäki', K Jansner', U Stenram² and K-G Tranberg*,I \\ 'Department of Surgery, Lund University, SE-22I 85 Lund, Sweden; '2Department of Pathology, Lund University, SE-22I 85 Lund, Sweden
}

\begin{abstract}
Previous studies in our laboratory have shown that interstitial laser thermotherapy (ILT) of an experimental liver tumour is superior to surgical excision, at least partly due to a laser-induced immunological effect. The aim of the present study was to investigate the time-response relationship of the ILT-induced immunisation and the cellular response of macrophages and lymphocytes. A dimethylhydrazine-induced adenocarcinoma was transplanted into the liver of syngeneic rats. Rats with tumour were treated 6-8 days later (tumour size $0.25-0.40 \mathrm{~cm}^{3}$ ) with ILT of tumour or resection of the tumour-bearing lobe. Two groups of rats without tumour were treated with resection of a normal liver lobe or ILT of normal liver. A challenging tumour was implanted into the liver of each rat 2, 5 or 10 weeks after primary treatment. Rats were killed 6, 12 and 48 days (or earlier due to their condition) after challenge ( $n=8$ in all groups). Immunohistochemical techniques were used to determine lymphocytes (CD8, CD4) and macrophages (EDI, ED2) in rats having had treatment of a primary tumour. Interstitial laser thermotherapy of the first tumour was followed by eradication of challenging tumour and absence of tumour spread. This contrasted with rapid growth and spread of challenging tumour in the other groups. In the challenging vital tumour tissue and in the interface between the tumour and surroundings, the number of EDI macrophages and CD8 lymphocytes was higher in rats having been treated with the ILT of tumour than in those having undergone resection of the tumour-bearing lobe. The number of ED2 macrophages and CD4 lymphocytes was low and did not vary between these two groups. Interstitial laser thermotherapy elicited an immune response that eradicated a challenging tumour and was associated with increased numbers of tumour-infiltrating macrophages and CD8 lymphocytes.
\end{abstract}

British Journal of Cancer (2005) 93, 435-440. doi: I 0.1038/sj.bjc.66027I8 www.bjcancer.com

Published online 9 August 2005

(c) 2005 Cancer Research UK

Keywords: interstitial laser thermotherapy; CD4 and CD8 lymphocytes; EDI and ED2 macrophages; immune response

In the future, curative treatment of solid tumours is likely to consist of local treatment (surgical excision or some form of local tissue destruction) coupled with different types of adjuvant therapy. The reason why local excision alone may not be sufficient for cure is the risk for occult disseminated disease and, also, the risk for local recurrence. Surgery is known to induce immunosuppression and the release of growth factors that may stimulate growth of residual tumour (discussed in Möller et al, 1998). The reason why systemic therapy like chemotherapy or immunotherapy is likely to be insufficient as the sole treatment is their relative inefficacy for solid tumours and the fact that clinical tumour burdens are large. As for immunotherapy, possible success appears to depend on combination with procedures that give efficient tumour killing and antigen exposure. Heating of tumour cells with interstitial laser thermotherapy (ILT) is interesting in this respect, since it can accomplish total local tumour destruction by tumour necrosis at the same time as it induces an immunological response against the tumour (Möller et al, 1998; Tranberg et al, 2002).

Using a model of adenocarcinoma implanted into rat liver, we reported that ILT gave results that were superior to those of

\footnotetext{
*Correspondence: Dr K-G Tranberg;

E-mail: Karl-Goran.Tranberg@med.lu.se

Revised 6 June 2005; accepted 20 June 2005; published online 9 August 2005
}

surgical resection of the tumour-bearing liver lobe (Möller et al, 1998). The efficacy of local tumour removal was similar, but the ILT method was associated with less extrahepatic spread. Evidence for a laser-induced immunological effect was then obtained by the following study. Using inoculation of tumour cell suspensions into the lateral and median lobes of the liver simultaneously and treating the lateral lobe tumour only, we found that laser thermotherapy reduced take and growth of the untreated tumour in the median lobe. This twin tumour study thus provided direct evidence that the advantageous effect of ILT can at least partly be explained by the induction of an immunological response (Tranberg et al, 2002).

The aim of the present study was to examine the time-response relationship of the ILT-induced immunisation and to elucidate the possible mechanisms by studying tissue densities of macrophages and CD4 and CD8 lymphocytes.

\section{MATERIAL AND METHODS}

\section{Animals and tumour}

The experiments were performed with male rats from Møllegaard A/S (Ejby, Denmark), but complementary studies were performed with Wistar FU from our own breeding. Rats weighed 224-292 g at 
the time of tumour implantation. They were housed individually and had free access to standard food pellets (Ewos R3; Lactamin AB, Södertälje, Sweden) and tap water ad libitum. The tumour was a dimethylhydrazine-induced, weakly immunogenic adenocarcinoma of the rat colon obtained from the Wallenberg Research Laboratory, Lund (Steele and Sjögren, 1974). The tumour was propagated by weekly intraperitoneal passages in inbred Wistar rats from our own breeding. Generations 140-154 were used in this study.

Tumour implantation was performed with vital and macroscopically homogenous tumour. At midline laparatomy and using an operating microscope (Olympus OMK 1, Olympus Optical, Tokyo, Japan), a 3-mm-long and 2-mm-deep incision was made on the anterior surface of the liver. A piece of Spongostan (Ferrosan A/S, Søborg, Denmark) was applied to the incision area for $5 \mathrm{~min}$ to control bleeding. A piece of the tumour ( $1.0 \mathrm{~mm}$ in diameter) was then implanted into the parenchyma, followed by application of Spongostan for another $2 \mathrm{~min}$. The first tumour (the tumour to be treated) was implanted into the left lateral lobe of the liver, whereas the second (challenging) tumour was implanted into the median lobe of the liver. Tumour preparations were made immediately before transplantation and were kept on ice cubes until implanted.

Rats were anaesthetised with an intraperitoneal injection of 5\% chloral hydrate $(0.5 \mathrm{mg}$ per $100 \mathrm{~g}$ body weight $)$ for tumour implantation. Ether was used for all other procedures that required anaesthesia, including treatments, challenges and euthanasia. All treatments were performed using a midline abdominal incision. Treatment procedures were followed by intramuscular injection of buprenorphine (Temgesic, Meda AB, Göteborg, Sweden), $0.002 \mathrm{mg}$ per $100 \mathrm{~g}$ body weight, for analgesia.

Animal procedures were performed according to the recommendations of the Swedish Board of Animal Research and were approved by the Committee of Animal Ethics at Lund University.

\section{Experimental protocol}

We used 288 rats which were randomly allocated to four groups. Two groups of rats with tumour (I-II) were treated with ILT of tumour (I) or resection of the tumour-bearing lobe (II). Two groups of rats without tumour (III-IV) were treated with resection of a normal liver lobe (III) or ILT of normal liver (IV). Treatment of rats with tumour (I-II) was performed 6-8 days after implantation, at which time tumour had a size of $140 \pm 25$ (mean \pm s.e.m.) $\mathrm{mm}^{3}$ and did not vary between the treatment groups $(P>0.05)$. A challenging tumour was implanted into the liver of each rat 2, 5 or 10 weeks after primary treatment (groups I-IV). Rats were planned to be killed 6,12 and 48 days after challenge ( $n=8$ in all groups). However, rats were euthanised as soon as they showed signs of inactivity or distress. At that time, there was usually palpable intraabdominal tumours.

After killing, the liver, lungs, peritoneum and all tissues containing suspect tumour growth were harvested for microscopic examination. Immunohistochemical examinations were carried out after challenge in rats having had treatment of a primary tumour (groups I-II).

\section{Interstitial laser thermotherapy (ILT)}

Thermotherapy was carried out with a system consisting of an $\mathrm{Nd}$ :YAG laser and a temperature feedback control unit interfaced with the laser, as described in detail elsewhere (Möller et al, 1996, 1997, 1998) (Figure 1). The laser beam was delivered through a $600-\mu \mathrm{m}$ flexible bare fibre at a laser output power of $2 \mathrm{~W}$. The bare fibre was placed at right angles into the centre of the tumour, at a depth measuring one-third of the thickness of the liver, including the tumour. A feedback thermistor probe (Microtherm AB, Lund, Sweden) was placed perpendicularly into the liver parenchyma at a distance of $3 \mathrm{~mm}$ from the tumour margin and at a depth of $2 \mathrm{~mm}$

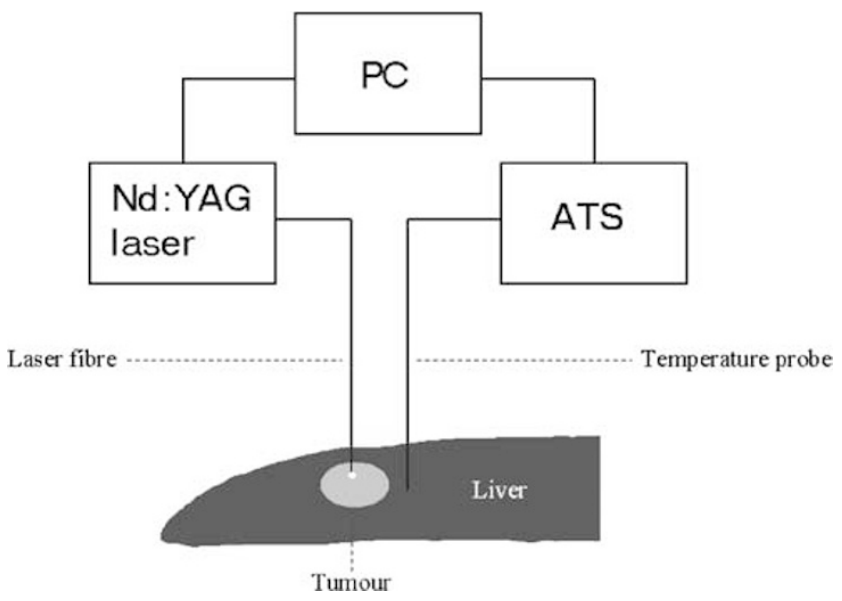

Figure I Schematic illustration of feedback temperature system for ILT ATS, automatic thermometry system; PC, personal computer.

from the liver surface. The distance from the tip of the bare fibre to the thermistor probe averaged $6.4 \pm 0.1$ (mean \pm s.e.m.) $\mathrm{mm}$.

Interstitial laser thermotherapy was performed at a steady-state target temperature of $46^{\circ} \mathrm{C}$ for $30 \mathrm{~min}$ at the thermistor probe, that is, $3 \mathrm{~mm}$ from the tumour margin. The treatment characteristics were based on previous studies defining the temperature and duration of treatment needed for complete tumour necrosis, as judged 6 days after treatment (Möller et al, 1996, 1997, 1998). Interstitial laser thermotherapy of normal liver was performed in the same way, using the distance between the laser fibre and thermistor probe found in rats with tumours.

\section{Resectional procedures}

Resection of the tumour-bearing, or normal, left lateral lobe was performed after division of the falciform ligament and the triangular plicae on the left side. A ligature of 4-0 Suturamid (Johnson and Johnson $\mathrm{AB}$, Sweden) was tied around the most central part of the venous and arterial pedicle to the left lateral liver lobe. The liver was transected with a pair of scissors $1-2 \mathrm{~mm}$ distal to the ligature and $10.3 \pm 0.4$ (mean \pm s.e.m., range $7.0-$ 15.0) $\mathrm{mm}$ proximal to the tumour, as measured macroscopically. A soft gauze was carefully placed under the left lateral liver lobe in order to collect possible bleeding from the resection line.

\section{Histopathology}

Liver tissues were fixed in $4 \%$ paraformaldehyde in $0.1 \mathrm{~m}$ sodium phosphate buffer (PB) as a rule for $24 \mathrm{~h}$. The livers with tumours were delivered uncut to the pathologist, who examined the specimens while unaware of the treatment. A section was cut through what was considered to be the largest diameter of the lesion(s), sometimes supplemented with one or two additional sections. The specimens were then rinsed, dehydrated and embedded in paraffin. After sectioning, the slides were processed for immunohistochemistry or stained with haematoxylin/eosin.

The sizes of total tumour and necrotic tumour were measured under the microscope with a micrometer, because it was impossible to distinguish necrosis, inflammatory changes and tumour with the naked eye, especially in rats that had been treated with laser thermotherapy.

\section{Immunohistochemistry}

The sections were deparaffinised with xylene and brought to $96 \%$ alcohol and washed in $0.1 \mathrm{~m}$ sodium phosphate-buffered saline 
(PBS) with $0.25 \%$ Triton $\mathrm{X}-100, \mathrm{pH}$ 7.2. Immunohistochemical reaction for tissue macrophages was performed with ED1 and ED2 mouse anti-rat antibodies (diluted 1:200) (Serotec Ltd, Oxford, UK), using a secondary rabbit anti-mouse antibody (Dijkstra et al, 1985; Damoiseaux et al 1994). Reaction for CD4 and CD8 was performed with mouse anti-rat antibodies (diluted $1: 200$ ) (Nordic Biosite AB, Täby, Sweden), using a secondary rabbit anti-mouse antibody (Whiteland et al, 1995). Visualisation was performed with diaminobenzidine (DAB) (Saveen Biotech AB, Malmö, Sweden) (brown colour). Counterstaining was made with haematoxylin ad modum Mayer. Negative controls (buffer instead of primary antibody) were performed to each reaction.

Labelled cells were counted per visual field with an $\times 40$ objective and an $\times 10$ ocular. As a rule, only whole fields were counted on peripheral vital tumour and granulation tissue. It was tried to count six fields for each type of tissue, but that was not always possible. For each rat, ED1, ED2, CD4 and CD8 slides were counted one after the other to ensure that the same areas were counted with all antibodies. The order of examination of slides varied. Necroses and large vessels were avoided. The mean per visual field was used in the statistical analysis.

\section{Calculations}

Lesion size $(V)$ was estimated according to the formula $V=a \times$ $b^{2} / 2$, where $a$ is the largest width and $b$ is the maximum diameter perpendicular to the width of the tumour (Carlsson et al, 1983). Before treatment, these measurements, including measurement of the liver thickness, were performed during laparotomy using a vernier caliper.

The significance of differences between groups was assessed with the Mann-Whitney test. Values are means \pm s.e.m. Probabilities of less than 0.05 were accepted as significant.

\section{RESULTS}

The tumour is a poorly differentiated carcinoma growing expansively in the liver without or with very little tissue reaction from the host. Tumours that were treated with resection had irregular necroses in the centre and were proliferating in the periphery with a rather smooth boundary to the surrounding liver tissue without inflammatory reaction, except for an occasional small area of granulation tissue. The microscopic changes seen a week after laser treatment have been described in detail in previous communications (Möller et al, 1996, 1997, 1998). Briefly, the treated tumour contains cells with faintly stained nuclei and eosinophilic cytoplasm, as a rule surrounded by a layer of necrotic liver tissue. In the peripheral parts of the necroses, there are polymorphonuclear leucocytes and macrophages and a few lymphocytes.

The growth of challenging liver tumours in groups I-II is summarised in Table 1. The challenging tumour after ILT of tumour (group I) was followed by eradication of reimplanted tumour at 48 days and absence of tumour spread. After 48 days, there was as a rule only a fibrous scar, included in Table 2 under 'tumour capsule', sometimes no remnant at all. This contrasted with the rapid growth and spread of tumour following implantation of tumour in the other groups (II-IV), leading to euthanasia of all animals within 30 days. In two of the ILT animals vital tumour cells were found at 48 days at immunohistochemistry, but not in haematoxylin-eosin sections. None of the rats that had undergone ILT of the first tumour showed evidence of ascites or extrahepatic spread (group I). All other rats had both extensive intraperitoneal tumour growth and ascites, with no obvious differences between rats that had undergone resection of the tumour-bearing left lateral liver lobe, resection of the normal left lateral liver lobe and ILT of normal liver (groups II-IV).

With the exception of the ILT animals, the tumours that were implanted into treated rats had the same appearance as the tumours that were resected before reimplantation. In rats treated with ILT, there appeared to be relatively large numbers of polymorphonuclear leucocytes in the peripheral parts of necrotic tumour.

The number of ED1 macrophages in tumour capsule and viable tumour was significantly larger in the ILT (group I) than in the resection groups (II) at 12 days after challenge $(P<0.05$ in both instances). The difference between the ILT and resection groups was more obvious for CD8 lymphocytes: numbers were larger in the ILT group both at 6 and 12 days after challenge, and both in the tumour capsule and in viable tumour $(P<0.05$ in all instances). ED2 and CD4 cells were always few, and there were no differences between the ILT and resection groups $(P>0.05)$ (Table 2). There was often a concentration of ED1 cells in the tumour periphery.

Table I Size of challenging tumour after treatment ( $n=8$ in each group)

\begin{tabular}{|c|c|c|c|c|}
\hline \multirow[b]{2}{*}{ Group } & \multirow[b]{2}{*}{$\begin{array}{c}\text { Implantation } \\
\text { post-treatment, } \\
\text { weeks }\end{array}$} & \multicolumn{3}{|c|}{$\begin{array}{c}\text { Vital tumour at killing }\left(\mathrm{mm}^{3}\right) \text {, days after implantation of } \\
\text { new tumour }\end{array}$} \\
\hline & & 6 days & 12 days & 48 days $^{a}$ \\
\hline I. Interstitial laser thermotherapy (ILT) of tumour & $\begin{array}{r}2 \\
5 \\
10\end{array}$ & $\begin{array}{l}34 \pm 15 \\
25 \pm 5.6 \\
6.6 \pm 3.4\end{array}$ & $\begin{array}{r}201 \pm 36 \\
150 \pm 66 \\
15 \pm 14\end{array}$ & $\begin{array}{c}1.0 \pm 1.0^{b} \\
0 \\
0\end{array}$ \\
\hline II. Resection of tumour-bearing liver lobe & $\begin{array}{r}2 \\
5 \\
10\end{array}$ & $\begin{array}{l}280 \pm 11 \\
336 \pm 16 \\
231 \pm 44\end{array}$ & $\begin{array}{c}204 \pm 25 \\
1836 \pm 249 \\
1787 \pm 341\end{array}$ & $\begin{array}{l}2493 \pm 405 \\
1321 \pm 250 \\
1779 \pm 339\end{array}$ \\
\hline III. Resection of normal liver lobe & $\begin{array}{r}2 \\
5 \\
10\end{array}$ & $\begin{array}{l}351 \pm 33 \\
282 \pm 25 \\
354 \pm 16\end{array}$ & $\begin{array}{c}426 \pm 81 \\
1741 \pm 311 \\
2272 \pm 319\end{array}$ & $\begin{array}{l}2372 \pm 396 \\
2319 \pm 381 \\
2843 \pm 365\end{array}$ \\
\hline
\end{tabular}

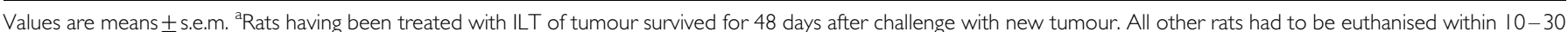
days with extensive tumour burden, intraperitoneal spread and ascites; these rats were included in the 48 -days column. ${ }^{\text {b}}$ Two tumours. 
Table 2 Density of EDI and ED2 macrophages and CD4 and CD8 lymphocytes in implanted tumour in treated rats ( $n=8$ in each group)

\begin{tabular}{|c|c|c|c|c|c|c|c|c|c|}
\hline \multirow[b]{2}{*}{ Group } & \multirow{2}{*}{$\begin{array}{l}\text { Implantation } \\
\text { post-treatment, } \\
\text { weeks/killing, } \\
\text { days after } \\
\text { challenge }\end{array}$} & \multicolumn{2}{|c|}{$\begin{array}{l}\text { EDI-positive } \\
\text { macrophages }^{\text {a }}\end{array}$} & \multicolumn{2}{|c|}{$\begin{array}{l}\text { ED2-positive } \\
\text { macrophages }^{\text {a }}\end{array}$} & \multicolumn{2}{|c|}{ CD4 lymphocytes ${ }^{a}$} & \multicolumn{2}{|c|}{ CD8 lymphocytes ${ }^{a}$} \\
\hline & & $\begin{array}{l}\text { Tumour } \\
\text { capsule }\end{array}$ & $\begin{array}{l}\text { Viable } \\
\text { tumour }\end{array}$ & $\begin{array}{l}\text { Tumor } \\
\text { capsule }\end{array}$ & $\begin{array}{l}\text { Viable } \\
\text { tumour }\end{array}$ & $\begin{array}{l}\text { Tumour } \\
\text { capsule }\end{array}$ & $\begin{array}{l}\text { Viable } \\
\text { tumour }\end{array}$ & $\begin{array}{l}\text { Tumour } \\
\text { capsule }\end{array}$ & $\begin{array}{l}\text { Viable } \\
\text { tumour }\end{array}$ \\
\hline & $\begin{array}{r}2 w / 6 d \\
5 w / 6 d \\
10 w / 6 d\end{array}$ & $\begin{array}{l}76 \pm 25 \\
58 \pm 14 \\
65 \pm 29\end{array}$ & $\begin{array}{l}74 \pm 24 \\
54 \pm 19 \\
79 \pm 13\end{array}$ & $\begin{array}{c}0.2 \pm 0.4 \\
0 \pm 0 \\
0.5 \pm 0.5\end{array}$ & $\begin{array}{l}0.8 \pm 1.0 \\
0.6 \pm 0.5 \\
0.5 \pm 0.5\end{array}$ & $\begin{array}{c}0.8 \pm 0.8 \\
0 \pm 0 \\
-\end{array}$ & $\begin{array}{c}0 \pm 0 \\
0 \pm 0 \\
0.3 \pm 0.5\end{array}$ & $\begin{array}{l}14 \pm 8.3 * \\
27 \pm 16 * \\
17 \pm 23 *\end{array}$ & $\begin{array}{l}15 \pm 7.6 * \\
20 \pm 22 * \\
9.8 \pm 6.1 *\end{array}$ \\
\hline & $\begin{array}{l}2 w / 12 d \\
5 w / 12 d \\
10 w / 12 d\end{array}$ & $\begin{array}{l}76 \pm 35 * \\
73 \pm 19 * \\
62 \pm 15\end{array}$ & $\begin{array}{l}64 \pm 29 * \\
73 \pm 31 * \\
65 \pm 22\end{array}$ & $\begin{array}{c}0.4 \pm 0.5 \\
0 \pm 0 \\
1.1 \pm 1.1\end{array}$ & $\begin{array}{c}- \\
0.6 \pm 1.0 \\
0.8 \pm 1.2\end{array}$ & $\begin{array}{l}0.5 \pm 0.9 \\
0.1 \pm 0.3 \\
1.4 \pm 1.3\end{array}$ & $\begin{array}{c}0 \pm 0 \\
0 \pm 0 \\
0.2 \pm 0.4\end{array}$ & $\begin{array}{l}29 \pm 24 * \\
20 \pm 12 * \\
12 \pm 13\end{array}$ & $\begin{array}{l}11 \pm 15 * \\
18 \pm 15 * \\
26 \pm 10\end{array}$ \\
\hline \multicolumn{10}{|c|}{$\begin{array}{l}\text { II. Resection of tumour- } \\
\text { bearing liver lobe }\end{array}$} \\
\hline & $\begin{array}{r}2 w / 6 d \\
5 w / 6 d \\
10 w / 6 d\end{array}$ & $\begin{array}{l}77 \pm 20 \\
63 \pm 13 \\
91 \pm 20\end{array}$ & $\begin{array}{l}73 \pm 18 \\
62 \pm 12 \\
89 \pm 29\end{array}$ & $\begin{array}{r}0.3 \pm 0.8 \\
1.2 \pm 1.6 \\
0.25 \pm 0.5\end{array}$ & $\begin{array}{l}0.1 \pm 0.4 \\
1.5 \pm 0.8 \\
1.0 \pm 1.4\end{array}$ & $\begin{array}{c}0.3 \pm 0.5 \\
0 \pm 0 \\
0.5 \pm 0.6\end{array}$ & $\begin{array}{c}0.7 \pm 0.8 \\
0 \pm 0 \\
0.6 \pm 0.5\end{array}$ & $\begin{array}{l}13 \pm 14 \\
17 \pm 16 \\
11 \pm 5.9\end{array}$ & $\begin{array}{r}10 \pm 5.2 \\
2.3 \pm 3.4 \\
14 \pm 7.8\end{array}$ \\
\hline & $\begin{array}{r}2 w / 12 d \\
5 w / 12 d \\
10 w / 12 d\end{array}$ & $\begin{array}{c}64 \pm 25 \\
58 \pm 14 \\
-\end{array}$ & $\begin{array}{c}54 \pm 29 \\
49 \pm 13 \\
-\end{array}$ & $\begin{array}{c}0.9 \pm 1.6 \\
0.3 \pm 0.5 \\
-\end{array}$ & $\begin{array}{c}0.4 \pm 0.5 \\
0.2 \pm 0.4 \\
-\end{array}$ & $\begin{array}{c}0 \pm 0 \\
0.2 \pm 0.4 \\
-\end{array}$ & $\begin{array}{c}0 \pm 0 \\
0.2 \pm 0.4 \\
-\end{array}$ & $\begin{array}{c}14 \pm 12 \\
17 \pm 8.4 \\
-\end{array}$ & $\begin{array}{c}12 \pm 8.6 \\
11 \pm 10 \\
-\end{array}$ \\
\hline & $2 w / 48 d^{c}$ & - & - & - & - & - & - & - & - \\
\hline & $\begin{array}{c}5 w / 48 d^{c} \\
10 w / 48 d^{c}\end{array}$ & $25 \pm 21$ & $\underline{0}$ & $1.0 \pm 1.7$ & $\begin{array}{c}1.0 \pm 1.4 \\
-\end{array}$ & $\begin{array}{c}1.0 \pm 1.4 \\
-\end{array}$ & $1.0 \pm 1.4$ & $\begin{array}{c}1.3 \pm 1.1 \\
-\end{array}$ & $\underline{0 \pm 0}$ \\
\hline
\end{tabular}

$\mathrm{w}=$ weeks; $\mathrm{d}=$ days. ${ }^{\mathrm{a}}$ Number of cells per visual field. ${ }^{\mathrm{b}}$ Two rats with signs of vital tumour in the liver. ${ }^{\mathrm{c}}$ Animals had to be euthanised I0 - 30 days after reimplantation and only two tumours were analysed. Values are means \pm s.e.m. $* P<0.05$ for comparisons between ILT and resection of tumour-bearing liver lobe. For comparison between treatments, values were pooled for each post-treatment challenge day, since there were no differences within each day for different weeks after treatment.

As a rule, ED1- and ED2-positive cells had the appearance of macrophages in vital tumour (Figure 2). In the granulation tissue, myofibroblast-like cells as well as macrophages were positive for both ED1 and ED2 antibodies. Generally, more macrophages than myofibroblast-like cells were positive. The number of macrophages in granulation tissue should be regarded with some caution, but it appears that ED1-positive cells should represent mainly macrophages in vital tumour tissue.

\section{DISCUSSION}

Local tumour therapy with hyperthermia focuses on two different aspects: (a) atraumatic reduction or ablation of tumour (Tranberg et al, 1996, 2002; Möller et al, 1998; Vogl et al, 1998; Isbert et al, 2002), and (b) induction of tumour immunity, alone or together with cytokine therapy (Möller et al, 1998; Tranberg et al, 2002; Dranoff, 2004). This study confirmed that laser thermotherapy can elicit a favourable immunological response at the same time as it eradicates the primary tumour, and showed that this response remains strong at least 10 weeks after treatment. It also showed that laser treatment was followed by an immune cellular response of tumour-infiltrating macrophages and CD8 lymphocytes.

CD8 lymphocytes and ED1 macrophages invaded the challenging tumour. This agrees with findings in studies in which antitumour immunity has been induced and where these two cell types have been found to be of importance (Caruso et al, 1993;
Barba et al, 1994; Consalvo et al, 1995; Yamamoto et al, 1997; Xiang et al, 1998; Kuriyama et al, 1999a, b). Antitumour immunity is a complex phenomenon. There is growing evidence that dendritic cells are important for induction of immunity (Todryk et al, 1999; Basu et al, 2000; Sauter et al, 2000). Other studies have suggested that CD4 cells (Caruso et al, 1993; Kuriyama et al, 1999a, b), natural killer cells (Pierrefite-Carle et al, 1999) and antibodies (Chen et al, 1999) also may play important roles. Futhermore, it appears that recognition of tumour antigens by $\mathrm{T}$ lymphocytes is not enough for efficient tumour cell killing and for elimination of the effect of tumour-induced immunosuppression (Horiguchi et al, 1999). Efficient immune therapy seems to require a local inflammatory reaction of a certain type coupled with the secretion of a mixture of appropriate cytokines (Ganss et al, 2002; Dranoff, 2004). The local presence of cytokines like IL-12, IL-18, INF- $\gamma$ or TNF- $\alpha$ helps to generate cytolytic effector cells.

Though we and the cited authors have used a syngeneic tumour model, it can be argued that the tumour was raised a long time ago, in our system 30 years ago. A genetic drift may have occurred, in the tumour and/or the rats, and transplantation antigens may have been responsible, at least in part, for the outcome. However, in our previous twin tumour study, the same effect was obtained in rats that were inoculated with a pure tumour cell suspension at two different sites in the liver (Tranberg et al, 2002), a model that carries a reduced risk of transplantation antigen involvement. In addition, we performed experiments also in another breed of the same syngeneic strain, and were pleased to obtain the same results 

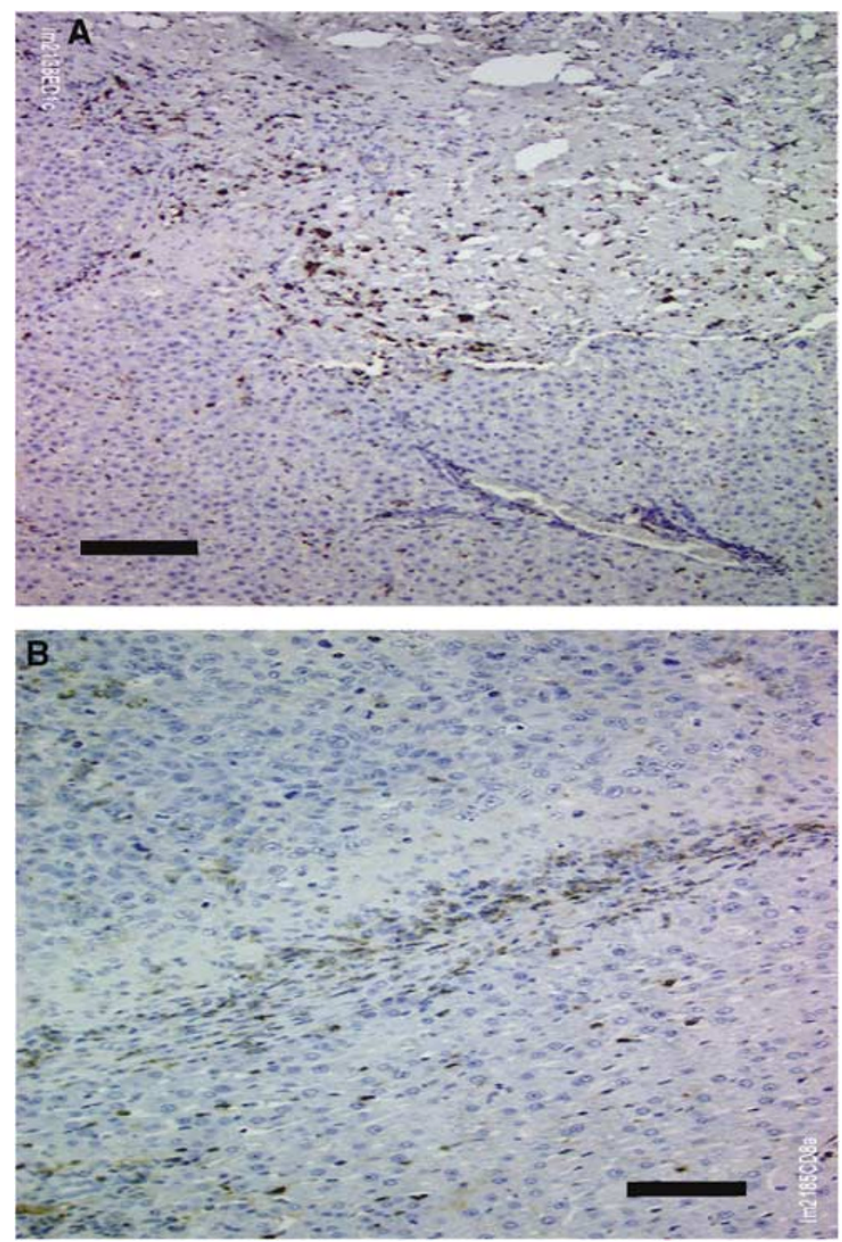

Figure 2 Immunohistochemical findings 12 days after rechallenge following ILT (group I). (A) Fibrotic remnants of tumour in the upper half, liver tissue in the lower half. Brown colour indicates EDI macrophages. Black bar: $50 \mu \mathrm{m}$. (B) Vital tumour from another animal, in the upper third of the photo, liver tissue in the lower half. Brown colour indicates CD8 lymphocytes. Black bar: $50 \mu \mathrm{m}$.

(data not shown). It would be of considerable interest to examine two quite different tumours in the same animal strain with similar or identical transplantation antigens.

Some of the elongated myofibroblast-like cells in the tumour capsule-granulation tissue stained positive with the ED1, and occasionally the ED2, macrophage and CD8 antibodies. Fibroblasts and endothelial cells have been described occasionally to be positive for ED1 (Damoiseaux et al, 1994). In the normal liver surrounding the tumour, we found plenty of elongated sinusoidal

\section{REFERENCES}

Barba D, Hardin J, Sadelain M, Gage FH (1994) Development of anti-tumor immunity following thymidine kinase-mediated killing of experimental brain tumors. Proc Natl Acad Sci USA 91: 4348-4352

Basu S, Binder RJ, Suto R, Anderson KM, Srivastava PK (2000) Necrotic but not apoptotic cell death releases heat shock proteins, which deliver a partial maturation signal to dendritic cells and activate the NF-kappaB pathway. Int Immunol 12: 1539-1546

Carlsson G, Gullberg B, Hafström L (1983) Estimation of liver tumor volume using different formulas: an experimental study in rats. J Cancer Res Clin Oncol 105: 20-23 cells positive with ED1. The most plausible explanation is that they are Kupffer cells, but we cannot exclude that some might be endothelial cells. Perhaps these elongated, ED1-positive cells might be incorporated into the capsule.

A vaccination effect has been suggested to be important for the effect of the two chemotherapy models cytosine deaminase/5fluorocytosine (Consalvo et al, 1995; Kuriyama et al, 1999b; Morris, 1999; Pierrefite-Carle et al, 1999) and herpes simplex virus thymidine kinase/ganciclovir (Barba et al, 1994; Yamamoto et al, 1997; Kuriyama et al, 1999a), and for the effect of photodynamic therapy (PDT) (Chen et al, 1997; Chen et al, 1999). These modalities induce tumour cell necrosis, and an inflammatory microenvironment, which is critical for eliciting an efficient immune response (Melcher et al, 1998; Todryk et al, 1999; Sauter et al, 2000). Cell death following irradiation, 'conventional' chemotherapy and conventional hyperthermia $\left(\leqslant 42.5^{\circ} \mathrm{C}\right)$ is mainly apoptotic (Cummings et al, 1997), which should give a less immunogenic response.

There is strong evidence that heat shock proteins (HSPs) are involved in mediating the immunological response against tumours. Heat shock protein - tumour peptide complexes are taken up by antigen-processing cells like macrophages/dendritic cells, where the tumour peptides are processed and presented to T cells, eliciting an immune response (Basu et al, 2000; Sauter et al, 2000; Srivastava, 2002). In our tumour model, ILT causes a shift of HSP70 from the cytoplasm to nucleus in tumour cells, an increase in tumour-infiltrating macrophages and an increase of HSP70 in ED1positive macrophages (Ivarsson et al, 2003). It has been shown that necrotic, but not apoptotic, cell death can cause the release of HSPs (Basu et al, 2000; Sauter et al, 2000; Srivastava, 2002).

The reason why we use the low temperature of $46^{\circ} \mathrm{C} 3 \mathrm{~mm}$ from the tumour margin (during $30 \mathrm{~min}$ ) is that we want to obtain cell death that develops into necrosis within a time range of hours to a few days (Wheatley et al, 1989). It is important that there is no coagulation of protein at this temperature level, which means that undestroyed tumour antigens can be exposed to the immune system. Furthermore, at this temperature, tumour blood flow is not abolished (Sturesson et al, 2005). Nevertheless, the ILT method produces complete necrosis of treated tumour (Möller et al, 1997, 1998; Tranberg et al, 2002).

In conclusion, laser thermotherapy appears to be a promising method for curative treatment of solid tumours. Hyperthermia may play an important role in immunotherapeutic approaches in the future.

\section{ACKNOWLEDGEMENTS}

This work was supported by grants from the Swedish Cancer Society (project no. 3163-B01-09XBB), the Crafoord Foundation, Lund University Hospital, Lundgren Foundation, GAE Nilsson Foundation for Cancer Treatment, John and Augusta Persson Foundation for Scientific Medical Research, and the Royal Physiographic Society in Lund.
Caruso M, Panis Y, Gagandeep S, Houssin D, Salzmann JL, Klatzmann D (1993) Regression of established macroscopic liver metastases after in situ transduction of a suicide gene. Proc Natl Acad Sci USA 90: 70247028

Chen WR, Adams RL, Carubelli R, Nordquist RE (1997) Laser-photosensitizer assisted immunotherapy: a novel modality for cancer treatment. Cancer Lett 115: 25-30

Chen WR, Zhu WG, Dynlacht JR, Liu H, Nordquist RE (1999) Long-term tumor resistance induced by laser photo-immunotherapy. Int $J$ Cancer 81: $808-812$ 
Consalvo M, Mullen CA, Modesti A, Musiani P, Allione A, Cavallo F, Giovarelli M, Forni G (1995) 5-Fluorocytosine-induced eradication of murine adenocarcinomas engineered to express the cytosine deaminase suicide gene requires host immune competence and leaves an efficient memory. J Immunol 154: 5302-5312

Cummings MC, Winterford CM, Walker NI (1997) Apoptosis (see comments). Am J Surg Pathol 21: 88-101

Damoiseaux JG, Dopp EA, Calame W, Chao D, MacPherson GG, Dijkstra CD (1994) Rat macrophage lysosomal membrane antigen recognized by monoclonal antibody ED1. Immunology 83: 140 - 147

Dijkstra CD, Dopp EA, Joling P, Kraal G (1985) The heterogeneity of mononuclear phagocytes in lymphoid organs: distinct macrophage subpopulations in the rat recognized by monoclonal antibodies ED1, ED2 and ED3. Immunology 54: 589-599

Dranoff G (2004) Cytokines in cancer pathogenesis and cancer therapy. Nat Rev Cancer 4: 11-22

Ganss R, Ryschich E, Klar E, Arnold B, Hammerling GJ (2002) Combination of T-cell therapy and trigger of inflammation induces remodeling of the vasculature and tumor eradication. Cancer Res 62: $1462-1470$

Horiguchi S, Petersson M, Nakazawa T, Kanda M, Zea AH, Ochoa AC, Kiessling R (1999) Primary chemically induced tumors induce profound immunosuppression concomitant with apoptosis and alterations in signal transduction in T cells and NK cells. Cancer Res 59: 2950-2956

Isbert C, Boerner A, Ritz JP, Schuppan D, Buhr HJ, Germer CT (2002) In situ ablation of experimental liver metastases delays and reduces residual intrahepatic tumour growth and peritoneal tumour spread compared with hepatic resection. Br J Surg 89: 1252-1259

Ivarsson K, Myllymaki L, Jansner K, Bruun A, Stenram U, Tranberg KG (2003) Heat shock protein 70 (HSP70) after laser thermotherapy of an adenocarcinoma transplanted into rat liver. Anticancer Res 23: $3703-3712$

Kuriyama S, Kikukawa M, Masui K, Okuda H, Nakatani T, Akahane T, Mitoro A, Tominaga K, Tsujinoue H, Yoshiji H, Okamoto S, Fukui H, Ikenaka K (1999a) Cancer gene therapy with HSV-tk/GCV system depends on T-cell-mediated immune responses and causes apoptotic death of tumor cells in vivo. Int J Cancer 83: 374-380

Kuriyama S, Kikukawa M, Masui K, Okuda H, Nakatani T, Sakamoto T, Yoshiji H, Fukui H, Ikenaka K, Mullen CA, Tsujii T (1999b) Cytosine deaminase/5-fluorocytosine gene therapy can induce efficient anti-tumor effects and protective immunity in immunocompetent mice but not in athymic nude mice. Int J Cancer 81: 592-597

Melcher A, Todryk S, Hardwick N, Ford M, Jacobson M, Vile RG (1998) Tumor immunogenicity is determined by the mechanism of cell death via induction of heat shock protein expression. Nature Med 4: $581-587$

Möller PH, Ivarsson K, Stenram U, Radnell M, Tranberg K-G (1997) Interstitial laser thermotherapy of an adenocarcinoma transplanted into rat liver. Eur J Surg 63: 867-870

Möller PH, Ivarsson K, Stenram U, Radnell M, Tranberg K-G (1998) Comparison between interstitial laser thermotherapy and excision of an adenocarcinoma transplanted into rat liver. Br J Cancer 77: 1884-1892
Möller PH, Lindberg L, Henriksson PH, Persson BRR, Tranberg K-G (1996) Temperature control and light penetration in a feedback interstitial laser thermotherapy system. Int J Hyperthermia 12: 49-63

Morris JC (1999) Enzyme/prodrug-based tumor vaccination: all politics (and immunity) are local. J Natl Cancer Inst 91: 1986-1989

Pierrefite-Carle V, Baque P, Gavelli A, Mala M, Chazal M, Gugenheim J, Bourgeon A, Milano G, Staccini P, Rossi B (1999) Cytosine deaminase/5fluorocytosine-based vaccination against liver tumors: evidence of distant bystander effect. J Natl Cancer Inst 91: 2014-2019

Sauter B, Albert ML, Francisco L, Larsson M, Somersan S, Bhardwaj N (2000) Consequences of cell death: exposure to necrotic tumor cells, but not primary tissue cells or apoptotic cells, induces the maturation of immunostimulatory dendritic cells. J Exp Med 191: 423-434

Srivastava P (2002) Roles of heat-shock proteins in innate and adaptive immunity. Nat Rev Immunol 2: 185 - 194

Steele GJ, Sjögren HO (1974) Cross-reacting tumor-associated antigen(s) among chemically induced rat colon carcinomas. Cancer Res 34: 1801 1807

Sturesson C, Ivarsson K, Stenram U, Andersson-Engels S (2005) Interstitial laser-induced thermotherapy of a rat liver tumour: effect of temperature and hepatic inflow occlusion. Radiat Res (in press)

Todryk S, Melcher AA, Hardwick N, Linardakis E, Bateman A, Colombo MP, Stoppacciaro A, Vile RG (1999) Heat shock protein 70 induced during tumor cell killing induces Th1 cytokines and targets immature dendritic cell precursors to enhance antigen uptake. J Immunol 163: $1398-1408$

Tranberg K-G, Möller PH, Hannesson P, Stenram U (1996) Interstitial laser treatment of malignant tumours: initial experience. Eur J Surg Oncol 22: $47-54$

Tranberg K-G, Myllymäki L, Möller PH, Ivarsson K, Sjögren HO (2002) Interstitial laser thermotherapy of a rat liver adenocarcinoma. J X-ray Sci Technol 10: $177-185$

Vogl TJ, Mack MG, Roggan A, Straub R, Eichler KC, Muller PK, Knappe V, Felix R (1998) Internally cooled power laser for MR-guided interstitial laser-induced thermotherapy of liver lesions: initial clinical results. Radiology 209: 381-385

Wheatley DN, Kerr C, Gregory DW (1989) Heat-induced damage to HeLaS3 cells: correlation of viability, permeability, osmosensitivity, phasecontrast light-, scanning electron-and transmission electron-microscopical findings. Int J Hyperthermia 5: 145-162

Whiteland JL, Nicholls SM, Shimeld C, Easty DL, Williams NA, Hill TJ (1995) Immunohistochemical detection of T-cell subsets and other leukocytes in paraffin-embedded rat and mouse tissues with monoclonal antibodies. J Histochem Cytochem 43: 313-320

Xiang R, Lode HN, Dreier T, Gillies SD, Reisfeld RA (1998) Induction of persistent tumor-protective immunity in mice cured of established colon carcinoma metastases. Cancer Res 58: 3918-3925

Yamamoto S, Suzuki S, Hoshino A, Akimoto M, Shimada T (1997) Herpes simplex virus thymidine kinase/ganciclovir-mediated killing of tumor cell induces tumor-specific cytotoxic T cells in mice. Cancer Gene Ther 4: $91-96$ 